\title{
Impious Heretics or Simple Birds? Alexander Farnese and Dutch Rebels in Post-Tassian Italian Poems
}

\section{Emma Grootveld and Nina Lamal}

Summary: This article examines the poetical construction of a hero and his enemies in two early seventeenth-century Italian poems about the siege of Antwerp (1584-85), Anversa Liberata and Anversa Conquistata (1609). It explores the adaptations of Tasso's Gerusalemme Liberata and Conquistata that made these models suitable to the new subject of the poems. From this perspective, we argue that the authors were more than servile epigones of Tasso, as the adaptations of Tasso's Gerusalemme in both poems created a compromise between the literary tradition and the historical context. The Dutch rebels, being reminiscences of Argillano's revolt, are characterised both as an errant enemy and a convertible community. Their double status enhances the complementary poetic representation of Alessandro Farnese, the army general fighting them as a clement "pious" hero. These representations and adaptations made it possible for the poems to finish with the reconversion of the Calvinist rebels and therefore both poems can be defined as "epic poems of reconciliation."

\section{Introduction}

In the eighth canto of the Gerusalemme Liberata, Torquato Tasso narrates the revolt of a group of Christian soldiers against their captain Godfrey of Bouillon (Goffredo). At the outset of the poem, Goffredo has been appointed by God to lead the first crusade against Jerusalem (1099), but now faces a serious challenge to his authority. Misled by infernal powers, the soldiers blame him and his fellow Frankish commanders for being impious and tyrannical towards their own army. While the soldiers prepare an armed mutiny, with all the appearance of a serious war, Goffredo prays. After his prayer, he appears before his soldiers, beaming 
with new light, and calls a halt to their "foolish menaces." The severe speech to his men is so impressive that not a single one dares to look-up at him. Without bloodshed Goffredo thus restores the order amongst his own troops, and resumes the preparations for the siege of Jerusalem.

Following the important studies by Sergio Zatti and David Quint, this passage (Gerusalemme Liberata VIII, 57-85) is now commonly known as "Argillano's revolt," referring to the soldier who is co-responsible for spreading the sedition amongst the troops. ${ }^{2}$ Quint in particular has examined the allegorical value of these verses and interpreted them in light of the political and religious conflicts of Tasso's own day. On the one hand, the long-lasting conflict with the Ottoman empire, culminating in the battle of Lepanto (1571), had certainly inspired Tasso in his choice of topic. On the other hand, Quint underscored that the growing popularity of Protestantism in Northern Europe had as well influenced the Liberata. ${ }^{3}$ As Quint observed, it may not have been a coincidence that the nations revolting against the authority of Goffredo in the eighth canto mainly consist of Swiss and English warriors, apart from Italians. In this view, Tasso's poem depicts a "double crusade: against the infidel outside the Church, against disunity and potential heresy within."4 Its militant compliance with heterodoxy makes the Gerusalemme Liberata one of the most eloquent expressions of Counter-Reformation ideology in European literature. This ideology is even more emphasised in the final version of the poem, Gerusalemme Conquistata (1593). ${ }^{5}$

Due to an increasing interest in ideology and imagology, this articulation of a post-Tridentine ethos and of heterodox otherness in Tasso's works and in those of his contemporaries and epigones has become an important topic within scholarly research. While Italian narratives on the conflicts between Christian armies

${ }^{1}$ GL VIII, 78-81. The editions of Torquato Tasso's poems used for this article are those by Franco Tomasi (Gerusalemme Liberata, from now on abbreviated in the footnotes as GL) and Luigi Bonfigli (Gerusalemme Conquistata: GC).

${ }^{2}$ Quint, Epic (214-221); Zatti, The Quest (135-159)

3 See for instance the observations in Turchi, "Riflessi" (390-392). See also Scavizzi, "Gerusalemme Liberata e Controriforma."

${ }^{4}$ Quint, Epic (215). Zatti has analysed the co-existence of these two clashes, the first between two opposed cultures, the second between two "codes engendered with the same culture and the same society," The Quest (137).

${ }^{5}$ Casella, "La Gerusalemme contro-riformata"; Gigante, Vincer pariemi; Girardi, Tasso e la nuova 'Gerusalemme'; Residori, Lidea del poema. Esp. part II (75-162). 
and non-Christian communities, such as Muslims and the native inhabitants of the Americas, have been the subject of several studies, this is not the case for poems dealing with the 'internal' conflict of the early modern European society, which concerned the Argillanos of the sixteenth century: the reformed enemy. ${ }^{6}$ Yet, such poems did exist both before and after Tasso. ${ }^{7}$ The aim of this article is to study the literary construction of a heterodox enemy and a Catholic hero in two such poems: Anversa Liberata and Anversa Conquistata. Both works recount the 1585 Catholic triumph by the Spanish-Habsburg army under the command of Alessandro Farnese, prince of Parma, over the Calvinist Republic of Antwerp. ${ }^{8}$ Antwerp would become the centrepiece of the prince's military campaign, which aimed to reconquer rebellious cities and provinces in the Low Countries. The Anversa Conquistata is a poem in loose hendecasyllables, written by Fortuniano Sanvitale and published in Parma in 1609. ' The Anversa Liberata consists of three cantos in ottava rima. The only surviving version of the text known to us is an unfinished manuscript of uncertain date, and its author remains unknown. ${ }^{10}$

The only explicit example mentioned by the author of the Anversa Conquistata is not Torquato Tasso, but Giovan Giorgio Trissino, author of L'Italia Liberata dai Goti (1547-8). Nevertheless, both poems are in many aspects indebted to Tasso's

\footnotetext{
${ }^{6}$ See amongst others Hester, "Failed New World Epics"; Murrin, History and Warfare; Gibellini, Limmagine di Lepanto; Mammana, Lèpanto. For the representation of religious otherness in the Gerusalemme and in other texts of the Renaissance, see also a volume edited by Zatti, $\mathrm{La}$ rappresentazione dell'altro.

${ }^{7}$ Examples before Tasso are by Girolamo Maggi or Magi, Cinque primi canti della guerra di Fiandra (Venezia, 1551) and Anton Francesco Olivieri or Oliviero, La Alamanna and Carlo Quinto in Olma (Venice, 1567); the most well-known example after Tasso is Roccella Espugnata by Francesco Bracciolini (Roma, 1630).

${ }^{8}$ Van der Essen, Alexandre Farnèse, Gouverneur-Général.

${ }^{9}$ Apart from Denarosi's cited work, studies on the Anversa Conquistata are by Bonardi, Fortuniano Sanvitale "delli Conti di Sala"; Salsano, Fortuniano Sanvitale. Modernizing interventions by the authors of this articles in spelling and punctuation of citations concern the adaptation of $v / u$, of the preposition $\dot{a}$ and the use of capitalizations.

${ }^{10}$ The only known version of the text is the manuscript Ms. cart. V-C-8 (formerly marked 48) in the Biblioteca Statale del Monumento Nazionale Badia di Cava. The text has been edited by Salsano in Giovan Battista Marino, Anversa Liberata, tre canti inediti. Salsano has attributed the authorship to Marino, but his hypothesis has recently been rejected. A brief overview of the attributional discussion concerning the Anversa Liberata is given by Denarosi, L'accademia degli Innominati di Parma (165-166). See also Russo, Autografi dei letterati italiani (289).
} 
example and can therefore be typified as 'post-Tassian'. ${ }^{11}$ Several nineteenth- and even twenty-first century critics have denounced this kind of post-Tassian poetry, written between the sixteenth and the seventeenth century and mainly modelled on Tasso's Gerusalemme Liberata (1581), as being too servile to its model to be considered original. The opinion that "the majority of the produced works only merits to be cited in so far as it testifies the continuous fortune of the maestro" is still a dominant one on seventeenth-century heroic poetry. ${ }^{12}$

Although we also depart from a comparison with the Tassian model, we do so in order to argue that the established connection with an epic tradition (and with Tasso's model in particular) results from dynamic operations of adjustments and inventions. Both in the Anversa Liberata and the Anversa Conquistata, the transformation of the Traci into contemporary Protestant rebels and of Goffredo into a clement Alessandro Farnese, is the starting point of an interdiscursive process of literary adaptation, whereby representational strategies of heroes and enemies present in Tasso's work interact with a specific contemporary historical setting. In both poems, the 'reconversion' of a rebel Protestant town entails particular image constructions of both the enemies and the central hero. These constructions can be linked to several literary models, especially but not exclusively to Tasso's Gerusalemme Liberata, as well as to specific elements of political discourse. The authors exploited features of epic common places and narrative devices through the use of characters with well-known precedents and meaningful names, dialogues in a particular setting, and meaningful ecphrases. Although Calvinists are constantly characterized by vices and associated with the forces of evil, their error is considered to be a temporary one, a consequence of their moral instability, blindness and naivety. This double status creates, as it were, a structural openness in the image of the enemy, as it creates the possibility of the Calvinists returning to the real faith and being pardoned by the hero. As such, the image of the enemies also serves the encomiastic purpose of the poems through the representation of the protagonist, Alessandro Farnese, as a 'pious' hero who is not just a courageous warrior, but also

\footnotetext{
11 The importance of Trissino's auctoritas in the Anversa Conquistata, as well as other poetic sources and models of the poems, are relevant topics which, however, are not covered in the limited scope of this article. With regard to post-Tassian poems, the most elaborate study is still Antonio Belloni's Gli epigoni, but see also Arbizzoni, Dopo Tasso and Foltran, Per un ciclo tassiano.

12 Pedullà, Il romanzo barocco. A remarkably negative judgement on the Anversa Liberata is expressed by Saccenti, Libri e maschere (28-40).
} 
an exemplary leader, capable of clemency and forgiveness whenever the occasion calls for it. The attribution of a clement ethos to the hero equally works from a narratological point of view: it favours a reading of the narratives as a kind of 'epic poems of reconciliation', despite their origins in bellicose models. ${ }^{13}$

\section{The siege of Antwerp (1584-1585): a Habsburg affair and a moral duty}

In the second half of the sixteenth century the spread of reformed convictions in the Netherlands went hand in hand with fierce political resistance against the Spanish-Habsburg rule of Philip II. ${ }^{14}$ The leading nobles desired a higher degree of participation in the decision-making and equally requested moderation towards the Calvinists. The iconoclastic fury of 1566 was the start of a revolt against Habsburg power that would last eighty years and would result in the establishment of a new state in the Northern Low Countries, the Dutch Republic. In 1578, Alessandro Farnese started a campaign to reconquer the rebellious cities and provinces. In July 1584 he besieged the Calvinist Republic of Antwerp, which, for various reasons, would become the centrepiece of his successful military campaign.

Antwerp was the most populous and commercial city of the Low Countries, and was also the centre of the Revolt against the Spanish-Habsburg monarchy. From 1577 onwards, Antwerp had become a Calvinist Republic and was governed during the siege by the burgomaster Marnix of Saint-Aldegonde, one of the key figures in the Revolt. Furthermore, Antwerp had the reputation of being impregnable. ${ }^{15}$ Nevertheless, after fourteen months Antwerp surrendered to Farnese and a peace treaty was signed. As was the case for most of the other cities conquered by Farnese in the Low Countries, he prevented Antwerp from being plundered and granted the citizens a full pardon. Antwerp's citizens obtained a ius emigrandi for four years, which gave Calvinists the choice either to convert to Catholicism or to leave the town. The siege of Antwerp thus ended with a rather peaceful reconciliation and reconversion, instead of a crushing battle. This strategy had not been used by earlier military commanders in the Netherlands and gave Farnese

\footnotetext{
13 This provisory term is inspired by the definition of Giovan Battista Marino's Adone as an 'epic poem of peace' by Jean Chapelain in his Lettre ou Discours [...] sur le poëme d'Adonis $d u$ Chevalier Marino, in reference to the exaltation of love in the poem. See also Bolzoni, "An Epic Poem of Peace."

${ }^{14}$ See Darby, The origins; Parker, The Dutch Revolt.

${ }^{15}$ Lombaerde, "Antwerp" (99-107).
} 
the reputation of a clement leader, both in the Low Countries and on the Italian peninsula. ${ }^{16}$

Soon after the surrender of Antwerp, this image was appropriated by filoFarnesian literary circles, as has amply been discussed by Lucia Denarosi in her study on the Parmesan academy of the Innominati, founded in $1574 .{ }^{17}$ Denarosi observed that from the 1580s onwards, the literary production of the Innominati was increasingly directed toward celebrating the members of the Farnese family. The successful campaign of Alessandro in the Netherlands, and especially the siege of Antwerp, created an opportunity to do so. In 1586, one year after the siege, Aurelio Orsi published the Latin poem De Bello Belgico. In the same year fifty authors, among whom Torquato Tasso, Erasmo di Valvasone, Scipione Ammirato and Maffeo Barberini, contributed to a collection of lyrical poems published under the direction of Giovanni Savorgnano. The siege of Antwerp continued to inspire courtiers and poets who wished to pay tribute to Alessandro Farnese and his offspring for several decades. One of these poets was the author of the Anversa Conquistata (1609) Fortuniano Sanvitale (1565-1626/7), who had become a member of the Innominati in 1593. Fortuniano's academic pseudonym 'Agitato' was probably related to personal troubles caused by his status as the illegitimate son of Giberto Sanvitale, Count of Sala (now Sala Baganza, a small village in the province of Parma). A number of litigations with his half-brother on financial issues forced him into exile at the end of the sixteenth century. ${ }^{18}$ Although little is known about the years of his exile, official documents show how in 1607 he obtained a revocation of the capitalis sententia, which allowed him to recuperate his rights on his heritage and to return to Parma. In light of these personal circumstances, the Anversa Conquistata can be considered a "clear homage to the clemency of the reigning house" of the Farnese, who granted him the right to return. ${ }^{19}$ Indeed, although his poem is dedicated to Alessandro's son cardinal Odoardo (1573-1626), the author declared that his intention was to provide a "forma di poetico panegirico di tutta la Serenissima Casa Farnese" (6).

\footnotetext{
16 See Soen, "Reconquista."

${ }^{17}$ See Denarosi, L'accademia (25-88).

${ }^{18}$ See Bonardi, "Vita” (263).

${ }^{19}$ Ivi, 271. All translations are our own.
} 
Even though the uncertainty about the author and the dating does not permit us to propose a similar contextualisation for the Anversa Liberata, one can assume that this poem was intended as a panegyric. The first canto equally contains a dedication to Odoardo Farnese, but it is not clear whether it refers to the Cardinal or to the grandson of Alessandro Farnese (1612-1646) who became duke of Parma in 1622. Furthermore, the three cantos were probably destined to be part of a broader epic project, as is indicated by a marginal note in the text. ${ }^{20}$

Both poems have an encomiastic purpose: to celebrate the heroic deeds of Alessandro Farnese. The image of their hero is situated in a narrative epic context and assumes complementary significations by means of different intertextual relations. Since the narratives on the campaign against the North-European city were inspired by the Tassian model of a crusade, a few words must be said about the mission both authors ascribed to Alessandro. As far as Tasso's Gerusalemme is concerned, the mission of the leading hero seems quite clear: to reconquer Jerusalem, one of the most holy places for Christians. This mission is only partially transferable to the context of the siege of Antwerp. According to a well-established biblical topos, Farnese's grandfather, the Holy Roman Emperor Charles V, tells his grandson, at the outset of the Anversa Conquistata, that it is his task to bring the Protestants of Antwerp back to the sacred fold. ${ }^{21}$ This message has both a political and religious value in the Conquistata and reflects the task the emperor had set

\footnotetext{
${ }^{20}$ One of the first scholars who examined the manuscript, Filippo Volpicella, advanced the hypothesis that the dedicatee was Duke Odoardo; "Di un poema" (55). He also signaled an important margin note on c.11r of the manuscript (omitted in Salsano's edition of the poem), observing that "di moltissimi canti esser dovea composto il poema; intantochè in una carta del suo manoscritto leggesi nel margine questa sua nota: 'Queste si mettano al canto 25: sieno queste 5 stanze” (55). Both issues have been studied by Giorgio Fulco. His accurate documentation, gathered in the last half of the past century as well as his annotations concerning the poem, conserved in the Centro Pio Rajna in Rome (contained in a not inventoried folder called Richerche sul ms. di Cava dei Tirreni dell'Anversa Liberata), point out that, notwithstanding his doubts, Fulco was inclined to identify the dedicatee with Odoardo II (see "Prove disattributive"). His attempts to identify the author of the poem led in several directions, such as the intellectual circle of Maffeo Barberini and Angelo Grillo, but as far as is known by the authors of this article, Fulco has never drawn a definite conclusion on this matter. We wish to thank the staff of the Centro Pio Rajna warmly for permitting us to consult the archive.
}

${ }^{21}$ Anversa Conquistata (AC) I, 40. "Che per tornar quella smarrita greggia / al sacro ovile, ha Dio Te solo eletto." This role was earlier attributed to Charles V in Ariosto's Orlando Furioso (1532), XV, 25-26. 
for himself, namely to reunite the Christian world under one religion and one political authority, respectively Catholic and Habsburg. ${ }^{22}$ Apart from being an important bulwark of Protestantism, Antwerp is also represented as the gateway to the rebellious provinces of the Northern Netherlands and to England ( $A C \mathrm{I}$, 92-4). From this point of view it is significant that it is Charles $V$ who appears in Farnese's dream, conferring a dynastical value to his actions: in this poem, the conquest of Antwerp is foremost a Habsburg affair. ${ }^{23}$

A similar connection between Alessandro and the Habsburg dynasty is made in the first canto of the Anversa Liberata, in which Farnese's mother Margherita tries to convince the Holy Virgin to support the battle of the Catholics by permitting her to assist her son personally. In general, however, the concern of territorial re-appropriation in Alessandro's mission is overshadowed in the Anversa Liberata by its religious significance: Farnese's principal goal can be found in the moral status of Antwerp. In the narrator's explanation of Antwerp's present condition, inconstancy is pinpointed as the main cause: at times the city is in a state of delirium, and sometimes it becomes strong again. According to the narrator, after various moments of religious error in the Middle Ages, Antwerp had relapsed when Luther reopened its gates to heresy and Calvin directed the desires of its wandering souls to embrace death ( $A L$ I, 73). The reason why Farnese has to subjugate the city, is to impede the dissemination of her vices.

Se la fibra maggior sangue sincero non porge all'altre, il corpo a morte è giunto:

da lei traggono e sangue e gli alimenti tutte del corpo belgico le genti.

Amor, dolor, pietà mosse il desio del gran Farnese a ristorarle i danni. (Anversa liberata, I, 74, 5-I, 75, 2)

\footnotetext{
${ }^{22}$ On this theme, see the online issue of E-Spania on the literary celebrations of Charles $\mathrm{V}$ of June 2012.

23 "Con le tue vittorie, / di cui fia tromba la verace fama, / te stesso inalza, e la real tua prole" (AC I, 44).
} 
Antwerp is presented here as the infected heart in the centre of the Low Countries, which clearly refers to the city as the centre of the Revolt against the Habsburg monarchy. To prevent the city from bringing all surrounding towns down to the same level, she has to be cut off. In this metaphorical characterization of the enemy, the author might have followed the description of one of its potential sources, the Assedio e Racquisto d'Anversa by Cesare Campana, who wrote that the malicious humours of the rebels originated from the heart of the Low Countries: from Antwerp, corrupted spirits ran through the limbs of the country and nourished the obstinate pestilence of rebellion. ${ }^{24}$ The employment of discursive elements of contemporary historiography makes the imaginary used to describe Antwerp rather specific, testifying to an interest for its religious context that went beyond flat epithets and formulas. ${ }^{25}$ At the same time the poet took full advantage of this political language in order to represent the siege foremost as a religious issue and a moral duty. He justifies in this way the necessity of Farnese's actions and, indirectly, of his own epic poem.

\section{Rebellious Calvinists and errant provinces}

The idea of Farnese's mission as a moral duty is further elaborated in the image of the rebels of Antwerp. At first glance, the rebels of Antwerp are characterized with the same stereotypical terms that were used by contemporaries to describe Islamic enemies: they are a setta infame, ostinati, insani, rubelli, superbi, alteri and demonstrate a general lack of respect for the Lord. ${ }^{26}$

\footnotetext{
24 "Era dunque ottimo consiglio, il voltar quivi tutte le forze, per opprimere i maligni humori de' ribelli, come luogo, ch'era senza dubbio il cuore di tutto quel corpo infetto, e donde scorrevano per gli altri membri quei corrotti spiriti, che nodrivano l'ostinata malvagità di cotal pestilenza," (Assedio 15-16). Campana could have been inspired by a letter of Pomponio Torelli; see Nori, "Una biografia parallela" (38). Campana's account was re-edited in his history on the Revolt in the Low Countries: Della Guerra. See De Groof, "Alexander Farnese" (195); Sabbadini, "L'uso della memoria." The hope of salvation for the Netherlands and the metaphor of the infected body were expressed similarly in other texts about the Netherlands, for example by the Venetian ambassador Badoaro; see De Keyser, Vreemde Ogen (206).

${ }^{25}$ For an overview of Italian reflections on the Dutch Revolt see Moretti, "La trattatistica italiana."

${ }^{26}$ For instance, $A L$ I, 6; I, 27-31; $A C$ II, 1; II, 3 4, to compare with, for instance, the reaction of the "pagani" to the Christian prayers in Gerusalemme Liberata XI, 12. See also Cerbo, "Camóes e Tasso."
} 
In the first canto of the Anversa Liberata, Farnese's mother Margherita makes a case for the necessity to provide divine assistance in the battle against the rebels (I, 21-32) by describing how their "sozzura infame" makes them curse the name of the Virgin, burn the altars with the fire of Calvin, trample the simulacra of the saints and kill the priests (I, 26-27). The image she sketches evokes both the blasphemy of Tasso's pagans and the historical iconoclastic fury of 1566, which had occurred during Margherita's time as the governess of the Low Countries. ${ }^{27}$ The city of Antwerp itself is associated with a dark, subterranean Hades, while her inhabitants are characterized as obstinate heretics eager to serve Pluto. ${ }^{28}$ Antwerp is linked to the underworld through the wizard Tanchellino, who is modelled upon the magician Ismeno of the Gerusalemme. ${ }^{29}$ Tanchellino is a character of historical inspiration as well: his name refers to Tanchelm, the leader of a heretical movement in the Netherlands, and especially in Antwerp, between the eleventh and the twelfth century. Tanchelm's movement is known in particular for his anti-sacerdotal ideas, which makes it an opportune precursor of Calvinism in the Catholic ecclesiastic imagery. ${ }^{30}$ Elsewhere, the poet calls it a "tenebroso orror di ria procella" and also remembers its expulsion by the holy Norbert of Xanten, who had been sent to Antwerp to fight Tanchellism (1124) and thus pre-dated the mission of Alessandro Farnese more than four hundred years. ${ }^{31}$ The appearance of the character Tanchellino in the Liberata is a typical example of the compromise the author attempted to find between the literary model of Tasso and the historical and legendary context of the besieged city, by which the rebels of Antwerp were, in a sense, assimilated to the pagans of the Gerusalemme.

\footnotetext{
${ }^{27}$ The theme of the passage recalls Ariosto's reference to the sack of Ravenna (1512) as well (Orlando Furioso XIV, 8).

28 "Troppo, in esse, ha vigor la fede avversa / a quella che da Pier fu data a Roma, / e dure ed ostinate ad ogni danno | per la città d'Inferno offrir si sanno" ( $A L \mathrm{I}, 6)$. See also $A L \mathrm{I}, 10,1-2$; I, 35-7; III, 13 etc.

${ }^{29}$ Both defined as "mago fellon" ( $\left.A L \mathrm{I}, 35 ; G L 18,48,1\right)$ they share their role as helper of the opposite camp with that of the hero, their identity as renegades of the Christian faith (II, 2) and their association with the spatial territory of the 'alta foresta' near to the city (see the cancelled stanza's in the 'Apparato e note' of the Anversa Liberata, p. 158 of the cited edition).

${ }^{30}$ See Russell, Dissent and Reform (56-68).

${ }^{31}$ See also the description in the cancelled octaves: "Antico eresiarca, al Nume eterno / sottrasse Anversa, e, mille infamie ordite, / quasi adorar si fece" ( $A L$, Apparato e note, p. 158).
} 
That these kinds of assimilations are not to be confused with simple superimpositions, can be demonstrated by the example of the most important character on Antwerp's side, the burgomaster Marnix of Saint-Aldegonde. ${ }^{32}$ In the Anversa Liberata he shares some features with Tasso's pagan hero Argante: he scorns death, is driven by an urge to punish his enemy and is impatient to demonstrate his force. ${ }^{33}$ Yet, in some respects Marnix is depicted more as a coward than as a contemporary reincarnation of Argante. His destiny contrasts the honourable ending of the Tassian hero, who dies in a duel with Tancredi (Gerusalemme Liberata XIX, 1-28). Instead, the burgomaster of Antwerp misses his opportunity for a glorious death: in the heat of the battle he is plucked out of the field by the local legendary giant Druon and put into the "molli piume" of his bed.
'Veggami pur sotto la spada esangue
morir trafitto il vincitore' ei dice
'non mi vedrà codardo'. E in questo punto
a scampo suo Druon l'orrendo è giunto.

Non fu permesso prima. (A miglior sorte

così forse, o Filippo, il Ciel ti serba).

Druon gl'involve in nube il petto forte

e delle piaghe il duol gli disacerba;

per aria il toglie al campo della morte

e ratto il porta alla città superba,

e nel suo albergo in molli piume il posa,

e lo consegna alla dolente sposa.

(Anversa Liberata I, 103, 5-104)

The narrator's comment underscores the image of Marnix as an anti-hero, deprived of a memorable death. The impression of parody in Marnix's salvation

\footnotetext{
${ }^{32}$ For the situation inside Antwerp and Marnix's leadership during the siege, see Marnef, "Burgemeester in moeilijke tijden."

${ }^{33}$ For example, "non prezza vita e non disprezza morte" ( $\left.A L \mathrm{I}, 85,3\right)$; cf. "Ho core anch'io che morte sprezza e crede / che ben si cambi con l'onor la vita" (GL XXII, 8, 1-2). "[...] e vuol repente / punir co '1 sangue l'inimico errore" ( $A L \mathrm{I}, 84,3-4)$; "e se ne va, con rapida prestezza, / superbo ad assaltar l'altrui fierezza" ( $A L \mathrm{I}, 85,7-8)$; cf. "Il feroce circasso uscí di stuolo, / ch'esser vols'egli il feritor primiero" (GL III, 34, 1-2).
} 
emerges even more when the passage is read against the background of Argante's state of mind on the morning of a great duel: Argante explicitly despises the "molli piume" and he cannot wait to exchange them for the hard grounds of the battlefield. ${ }^{34}$ Marnix, on the contrary, will never get out of bed in the unfinished Anversa Liberata. $^{35}$

In light of Quint's aforementioned interpretation of the Argillano's revolt as a Protestant insurrection, it is therefore significant that the characterisation of Marnix in the Anversa Liberata also recalls Tasso's Argillano. Argillano is "pronto di man, di lingua ardito," "impetuoso e fervido d'ingegno," while Marnix is described as being "d'ardente cor, di provido disegno," "alto d'ingegno." They are both associated with civil discord: Argillano was raised "ne le risse civil d'odio e di sdegno" (GL VIII, 58); Marnix "apre le porte / alla cittade insieme et allo sdegno" $(A L \mathrm{I}, 85){ }^{36}$

This association of Marnix and Argillano is more evident in the Anversa Conquistata, where Marnix is depicted as a sneaky and eloquent man and is equally held responsible for stirring up the civil strife in Antwerp. ${ }^{37}$ In the second book, an infernal council is followed by several demonical actions to sabotage the construction of a bridge by Farnese across the river Scheldt. For this episode the author has obviously been inspired by the famous canto IV of the Gerusalemme. ${ }^{38}$

\footnotetext{
34 “[...] Argante audace / le molli piume di calcar non gode: / tanto è nel ferro petto odio di pace, / desio di sangue ostile, amor di lode, / ché de le piaghe sue non sano ancora, / brama che 'l novo dí porti l'aurora" (GL VII, 50, 3-8).

${ }^{35}$ In his real life however, instead of dying in a duel or converting to Catholicism like Tasso's heroes, Marnix would emigrate to the Dutch Republic, dedicating the rest of his life to a translation of the Bible and to the writing of several anti-Catholic treatises.

${ }^{36}$ Note the rhyme ingegno : sdegno : regno $(G L)$; disegno : ingegno : sdegno $(A L)$.

37 Especially "et [Anversa] havria preso d'humiltà sembianza, / se di speme, e d'ardir non riempiva / a' gli Anversani l'Aldegonda i cori” ( $A C$ II, 133-5).

${ }^{38}$ As in canto XIII of the $G L$, in $A C$ III, 18-68 Farnese's soldiers try to gain wood in the forest near the besieged city in order to recover the destroyed war machinery. The soldiers are chased away by demons, but the solution is quite more simple in the $A C$ than in the Gerusalemme: when Alessandro is informed of this obstacle, he only needs to pray and ask God to send these spirits back into the dark Averno. Only Pluto bites his lip when his demons return into hell ("[...] Pluto, / che per dolor le labbra ambe si morse, / veggendo, che rifar doveasi il ponte" (AC III, 63-65; cf. GL IV, 1, 5-6: "e scorgendoli omai lieti e contenti, / ambo le labra per furor si morse").
} 
During the following night Alecto, the fury of discord, encourages Marnix to persist in his refusal to start peace talks with Farnese. This passage in the Anversa Conquistata is very similar to what happens in the eight canto of the Gerusalemme Liberata:

Havea col nero suo mille vaghezze tolto del giorno omai la notte oscura, ogni animal, qual fra le selve, e i boschi qual su le frondi, e qual su l'erba steso prendea riposo. Ma tu sol non dormi console vigilante, in cure involto, rivolgi nel tuo cor più d'un pensiero.
Sorgea la notte intanto, e sotto l'ali ricopriva del cielo i campi immensi; e 'l sonno, ozio de l' alme, oblio de' mali, lusingando sopia le cure e i sensi. Tu sol punto, Argillan, d'acuti strali d'aspro dolor, volgi gran cose e pensi, né l'agitato sen né gli occhi ponno la quiete raccòrre o '1 molle sonno.

(Anversa Conquistata, II, 141-7)

(Gerusalemme Liberata VIII, 57) ${ }^{39}$

The introduction of the scenes happens through the evocation of a restful nocturnal setting. This establishes a sharp contrast with the mental agitation of the characters, which are in both cases apostrophised by the narrator. In both poems, this mental condition attracts an intervention by Aletto. In the verses that follow, there are no direct textual echoes in the verses, but the implications are similar. In the Gerusalemme, Alecto appears in a dream to Argillano in the guise of Rinaldo's cadaver. Rinaldo's bloody head tells Argillano that Goffredo killed him. If Argillano and his fellow Italian knights do not appease the "tiranno esangue" or escape, then Goffredo will kill them too. Argillano, "sbigottito," calls the Italian knights together "con importuna fretta" and tells them to revolt against Goffredo and the other Frankish tyrants, referring to the horrible example of Rinaldo. ${ }^{40}$

Analogously, in the Anversa Conquistata Alecto fills Marnix with anxiety and impatience, this time by sending one of the serpents she has on her head

\footnotetext{
${ }^{39}$ Alecto's intervention reinforces the direct link between the Gerusalemme and the Anversa. Both passages have a precedent in the Orlando Furioso (VIII, 79, 5-8), where Alecto is absent.

40 "Si rompe il sonno, e sbigottito ei gira / gli occhi gonfi di rabbia e di veneno; / ed armato ch'egli è, con importuna / fretta i guerrier d'Italia insieme aduna" (GL VIII, 62, 5-8); "dunque un popolo barbaro e tiranno, $[\ldots]$ che non fu mai di sangue e d'or satollo, / ne terrà 'l freno in bocca e "l giogo al collo" (GL, VIII, 63, 5-8); "Che spettacolo, oimè, crudele e duro! / Quai frode di Goffredo a noi predice!” (GL VIII, 68, 5-6).
} 
in the direction of his heart. ${ }^{41}$ Although Marnix is more thoughtful and less ferocious than Argillano, he too orders his people to take part in an emergency deliberation. In his following speech he sternly insists on resisting Farnese's attempt to reintegrate them under Spanish rule. This particular speech is, for the largest part, based on Marnix' monologue in the account of the siege written by Cesare Campana, ${ }^{42}$ but some of his arguments equally correspond to those put forward by Argillano. He accuses the Spanish of tyranny and avidity, ${ }^{43}$ and recalls the other victims of their regime ${ }^{44}$ with the aim to continue the revolt against their oppressors.

Just like Argillano's speech leads to a revolt against the so-called Frankish tyrants, Marnix' ardent plea is followed by an attack on the bridge over the river Scheldt, which Farnese and his army had constructed in order to isolate the city of Antwerp by closing this important waterway. Campana described how Farnese escaped the attack: he moved away from the bridge just before it was partly blown up together with hundreds of his men. ${ }^{45}$ Like others (Campana's 'huomini più pij') had done, Sanvitale attributes his preservation to divine powers. The model of this salvation can again be found in canto VIII of the Gerusalemme, where Goffredo is protected against a violent attack of his revolting soldiers: ${ }^{46}$
È fama, che celeste spirto amico
È fama che fu visto in volto crudo del pio Alessandro gli porgesse aita; [...] ed in atto feroce e minacciante

\footnotetext{
41 "Impaciente già d'ogni dimora / salta del letto, e tacito, e pensoso / fra se discorre, con qual arte affreni / l'insana plebe, al fin di mille à questo / pensier s'appiglia [...] Il timore, e la morte homai presente, / minaccianti à la Terra, in se discorde, / impone al popol suo, che si raccolga" (AC II, 162-172).

${ }^{42}$ Campana, Assedio (31-36).

43 "gli ispani aversi, / che braman solo il giogo al collo imporne'; 'gente avida solo / di succiar da le vene il nostro sangue" (AC II, 184-5).

44 "E se ciò non vi move, almen vi pieghi, / anzi spaventi il duro essempio altrui" ( $A C$ II, 209-10).

${ }^{45}$ Campana, Assedio (47-49). "Il Prencipe dopo lo svanir del fuoco superficiale, et il volar della prima barca, parendogli ridicola inventione [...] si ritirò nel vicino forte di Santamaria; il che dagli huomini piu pij fu poi giudicato, esser' avvenuto per manifesta ispiration divina; ma l'apparente cagion fu questa, che non veggendo sua Altezza comparer' altro apparecchio de' nemici, non giudicò esser di bisogno maggior provisione [...].” (47-48).

${ }^{46}$ Likewise, Tasso describes the angel's shield as made of diamond in GL VII, 82.
} 
Quì l'Angelo di Dio da prima scielto a la custodia de l'invitto Eroe con lo scudo il coperse adamantino, con cui diffender suole il Padre eterno le città, le provincie, i giusti regi, et lo diffese, $\&$ lo sottrasse à morte. un alato guerrier tener lo scudo de la difesa al pio Buglion davante, e vibrar fulminando il ferro ignudo che di sangue vedeasi ancor stillante: sangue era forse di città, di regni, che provocàr del Cielo i tardi sdegni.

These examples demonstrate that the most important characters in the Calvinist revolt of Antwerp against the Catholic Habsburg domination were not only modelled on the Tassian pagans, but also on his sedative Christian knights. Sanvitale, in particular, borrowed from Tasso's example and adapted it to the historical context and sources of the Dutch Revolt. This means that Quint's interpretation of Argillano's mutiny as a Protestant revolt may have been shared by Tasso's epigones. Vicious as he was, Argillano was still a Christian, just like Marnix. But whereas Tasso allowed moral instability amongst the warriors of God in his design of a double crusade, the authors of both Anverse concentrated all rebellious elements within the city walls of Antwerp, the only place where moral instability reigned. Indeed, whenever the Catholic army is represented, it behaves exemplarily: the soldiers are dedicated and Farnese's leadership is absolute. ${ }^{47}$ This sets them apart from the citizens of Antwerp, who are primarily reigned by discord. The ancient topos of tumult in a besieged city is employed in accordance with the historical situation in Antwerp, where a part of the Catholic inhabitants started to meet each other in public, as their desire to surrender grew stronger. ${ }^{48}$ The dissension caused by the different groups and their opinions are represented as a "guerra civile" in the Anversa Liberata, which would urge the city to open the gates to Farnese. ${ }^{49}$ In a council preceding the siege in the Anversa Conquistata, Farnese even mentions the discord in Antwerp as one of the decisive factors to

\footnotetext{
${ }^{47}$ Farnese's leadership of the Catholic army in the Anversa Conquistata could be characterized as "al suo voler concorde scopre / esser de suoi guerrier la mente ardita" (AC I, 114-115).

${ }^{48}$ See, for instance, Aen. XII, 583: "Exoritur trepidos inter discordia civis.”

${ }^{49}$ According to the prediction made by Alessandro's mother Margherita, "molti, a guerra civil volte le brame, / minacceranno agli empi ostile oltraggio, / e quei c'hanno in orror la setta infame / porrà nel campo tuo notturno raggio: / cittadina discordia agevolmente / apre le porte a capitan prudente." (AL I, 52, 3-8)
} 
besiege the city. According to Farnese's speech, Antwerp may have had a high number of defenders, but would not offer too much resistance because of a lack of military leadership and, especially, because the discord and confusion amongst her inhabitants would create the "varco" permitting his access. ${ }^{50}$ In fact, in contrast to Tasso, disunity and errancy are uniquely related to the enemy camp. Like discord, the concept of deviation, "errare," which is in the epic-chivalric tradition closely associated with Christian knights, is used in the poems to describe the opposite camp. For instance, the situation Farnese has to face in Flanders is introduced as follows in the Anversa Liberata:

Quindi al nemico ardir tanti anni e tanti espose il pio Farnese il regio petto : domò genti e citta che, ribellanti, diero all'empio Calvin interno affetto, spense il furor delle province erranti nel sangue tolto lor dal proprio petto : tolto malgrado suo, perché 'n quel core sdegno non è cui non comandi Amore. (Anversa Liberata I, 7)

The "compagni erranti" in the protasis of the Gerusalemme Liberata are significantly replaced by "provincie erranti": a conflict which was internal to the Christian army in Tasso's poem now changed perspective and bestowed an antagonistic status on the 'erranti'. In a sense, the Calvinists in Antwerp thus assumed both the enmity of Tasso's pagans and the moral desertion of his errant fellows. In this new scheme, the attitude of the leading hero, who is responsible for the victims of the siege, changes as well. The authors attributed to the heroic character of Farnese a disposition that inspired him love rather than violence, and that made him spill the rebels' blood despite himself ("malgrado suo").

\footnotetext{
50 “[...] molti sono i diffensor: ma sono / tutti fra lor discordi, e senza capo, / che sia di Marte ne gli affari esperto. / Andiam dunque alle mura, che a la nostra / vista nascer colà potria tumulto, / e co 'l tumulto agevolarsi il varco; / Ne già dubiti alcun, che manchi 'l vitto. / Mentre d'assedio la città sia cinta, / ch'oltre ch'ei sarà breve havremo contra / popol molto confuso, e de lo Scalde / provisto habbiam come serrare il passo" ( $A C \mathrm{I}, 74-84)$; "Il timore, e la morte homai presente, / minaccianti a la Terra, in se discorde" ( $A C$ II, 170-1).
} 


\section{Blind moles and simple birds: a plea for salvation}

The rebels of Antwerp are thus being depicted as heretics through an emphasis on their obstinate rebellion, foolishness, discord and error. However, it is important to note that at several pivotal instances they are also being pardoned for these sins, especially in the Anversa Liberata. The ways in which the Catholic characters of the poem deal with rebels shows, from another point of view, why they are not fully assimilated with Tasso's pagans, nor with other contemporary enemies.

As early as in the first canto of the Anversa Liberata, clues are given that not all the citizens of Antwerp are considered lost heretics who cannot be converted. In the aforementioned plea, by which Farnese's mother Margherita convinces the Virgin to let her intervene in the battle, she adds to her argumentation that those who refuse the light of Heaven and prefer to live as obstinate moles deserve to live in obscurity. ${ }^{51}$ Yet, for the people who take off their blinders she pleads for salvation:

Ma chi l'oscuritade alluma, e toglie

le squamme a gli occhi onde si veggia il die,

per che languir tra le notturne doglie

e a morte inaudita aprir le vie?

(Anversa Liberata I, 32, 1-4)

Such a view on the enemy has its consequences for the ending of the siege. As she will tell her son when she appears before him to predict his victory, ${ }^{52}$

\footnotetext{
51 "Le tenebrose pene a lor si danno / che la luce del Ciel non voller mai : / e 'ndegno è d'aprir gli occhi empio che vuole / esser talpa ostinata a' rai del sole" (AL I, 31, 4-8). This recurrence to the Virgin is significant because Alessandro Farnese attributed his successful siege of Antwerp to the assistance of the Virgin herself. See Van der Essen, "Alexandre Farnèse, Homme d'état chrétien" (79).

52 This commonplace will be repeated in the third canto by Alessandro's guardian angel. A similar role was performed in the Gerusalemme by angel Gabriel (GL I, 17 and GC I, 21), but the 'motherly' scene might be even closer to Virgil's Aeneid, where Venus, disguised as a hunter looking for her sisters (I, 314-410), appeared to her son. In the Anversa Liberata, Margherita is transformed into a young soldier who lost his general (I, 40-58). At her subsequent revelation, the recognition by Alexander (I, 59: "m'inganni con mentita imago?") follows the Aeneid ("Quid natum totiens, crudelis tu quoque, falsis | ludis imaginibus?," Aen. 407-408).
} 
Heaven will not consent to a total destruction of the enemy. Even if the city is in the hands of the Calvinists, there are still many Catholic inhabitants and it would be unjust to punish those who haven't committed any crimes. ${ }^{53}$ According to Margherita, hunger and civil war will force the inhabitants to open their city gates for the prudent captain Farnese, and it will not be necessary to destroy the city. Her prediction implies that this siege will not end in a classical massacre, like those of Vergil's Troy or Tasso's Jerusalem.

This attitude towards the rebels of Antwerp is further elaborated in the third canto of the Anversa Liberata, when Farnese has some doubts about his mission and explains his sorrows while praying to God (Anversa Liberata III, 2-7). What troubles him fundamentally is the justification of war, and he wonders how long God's rage against the heretics of Antwerp will last. It is true that they have sinned and have refused to open their minds to God, but they could be saved if the Lord just showed them the light. According to Farnese, the cities of the Netherlands had once belonged to God, but the inhabitants have subsequently been seduced by 'the King of the eternal death'. The metaphor used by Farnese for these errant people of Antwerp is the one of drowsy and simple birds, who have confused the untrue flame coming from Calvin's bow with the morning light. As these birds dedicated their chants to the wrong light, they have already fallen prey to heresy:

Signor, con fiamma ingannatrice alletta arcier notturno il semplice augellino, che scuote il sonno in su l'amata vetta, fra gli smeraldi del nativo pino, e stimando quel lume aurea saetta del nato sol nel lucido mattino, sorge per onorar que' rai co 'l canto: e morto o prigionier si trova intanto.

Insidioso arcier, Calvino aprìo su la face infernal mentito lume, e' raggi al guardo sonnacchioso offrìo di questi augelli ancor d'inferme piume, che, credendo tua luce il foco rio,

\footnotetext{
53 "gente fidel v'è molta, e non è dritto / ch'ivi sia pena ove non è delitto" ( $A L \mathrm{I}, 50)$.
} 
son nella notte dello stigio fiume

morti non già, ché desteransi ancora

se 'l guardo tuo gli punge e gli avvalora.

(Anversa Liberata III, 5-6)

This passage contains several significant elements. The reference to Calvin as insidioso arcier designates the new religious situation by the use of a traditional theme. While his illusive flame reminds the deceiving abilities of the fury of discord Aletto, the figure of the archer is a Virgilian topos. In the Aeneid as vulgarized by Annibale Caro (1581), the insidioso arcier had appeared in the similitude of the stricken deer to which Dido was compared while she was foolishly in love. ${ }^{54}$ Earlier, Petrarch had cited this passage from the Aeneid in the third dialogue of his Secretum, where he compared himself to Virgil's deer to explain his wandering as a search for freedom. In contemporary Italian discourse on the Dutch Revolt, a similar desire for liberty was often given as an explanation for the outbreak of their insurrection, and was presented as such in the other poem about the siege of Antwerp, the Anversa Conquistata. ${ }^{55}$ Whether intentionally or by coincidence, the image of the archer produces an intertextual connection which elevates its semantic value within the contextual leitmotif of wandering and liberty.

Furthermore, Antwerp is represented as a land of God, whose inhabitants had been obedient Christians until very recently. The justification Farnese gives for the errors of the people of Antwerp is striking: they don't bear full responsibility for their heresy, but were deceived victims and thus deserve to be saved. Again, Farnese's situation is remarkably similar to that of Goffredo in the eighth canto of the Gerusalemme. Goffredo's reaction on the revolt is a prayer:

Signor, tu che sai ben con quanto zelo

la destra mia del civil sangue aborre,

tu squarcia a questi de la mente il velo,

e reprimi il furor che sí trascorre;

\footnotetext{
${ }^{54}$ L'Eneide di Virgilio, del commendatore Annibal Caro (Venezia, Giunti, 1581), IV, 68-72.

55 The remarks of the Venetian ambassador Tiepolo in his 'relazione' of August 1567 are exemplary: "sendo ognuno per natura pronto alla libertà, ma i fiamminghi massimamente, che sempre vissero liberi," Albèri, Relazioni (133). The most famous example is the Relazione of Cardinal Guido Bentivoglio (Antwerp, 1629).
} 
e l'innocenza mia, che costà sopra

è nota, al mondo cieco anco si scopra.

(Gerusalemme Liberata VIII, 76, 3-8)

Goffredo insists in his prayer on his refusal to use violence against his rebels, and asks God, instead, to lift the veils that cover their minds. Farnese, in turn, demands the same in his prayer for the heretics in Antwerp:

vibra tuo foco, e la sua luce altera

l'alma disombri, e ' 1 peccator non pera.

(Anversa Liberata III, 3, 7-8) ${ }^{56}$

These arguments already hint towards a conclusion of the siege of Antwerp in which the 'civil sangue' of the masses will be spared as much as possible. This ending is indeed predicted by Farnese's guardian angel, who responds to the prayer by assuring that most of the people of Antwerp will surrender and return to the Catholic faith:

Questi [i preghi tuoi] impetrâr ch'al fulminar del brando

vittorioso tuo non cada estinto

quant'egli è tutto il popolo nefando,

nell'ostinata perfidia avvinto:

n'andranno in pezzi i più nocenti; e quando

in sanguinosi gorghi al mar fia spinto

il veleno pestifero, al tuo piede

darà 'l servaggio e prenderà la fede.

(Anversa Liberata, III, 17)

The solution of the siege announced by the guardian angel recalls the measure taken by Goffredo after the revolt in his army. Goffredo only punishes the leader of the mutiny (Argillano); ${ }^{57}$ Farnese would only eliminate the most harmful ("i più nocenti") amongst the Dutch rebels. Yet, how this would have ended,

\footnotetext{
${ }^{56}$ Or again, in III, 4, 7-8: "Scuopri il tuo sole, e ben vedrai ch'a volo / trarralle a si bel lume un raggio solo."

57 "Co 'l sangue suo lavi il comun difetto / solo Argillan, di tante colpe autore, / che, mosso a leggierissimo sospetto, / sospinti gli altri ha nel medesmo errore.” (GL, VIII, 81, 1-4).
} 
cannot be read in the Anversa Liberata, since the poem is interrupted before the termination of the siege.

\section{'Accordianci co'l Prence': the rebels surrender}

A solution to end the siege can be found in the Anversa Conquistata. Since the siege of Antwerp was concluded with a peace treaty instead of a classical epic massacre, the author had to find an alternative way to represent the end of the siege.

Compared to the Anversa Liberata, the Conquistata remains closer to Campana's history and describes several failed attacks against the Catholic besiegers, as well as the decisive battle at the Counterdike. However, Sanvitale did not find material in Campana's history for the very end of the siege, which Campana had not elaborated upon.

The fourth book of the Anversa Conquistata narrates how the inhabitants become increasingly aware of their decreasing chances to be relieved and decide to deliberate in a council whether or not they should surrender. A recent model for a similar council was present in the tenth canto of the Gerusalemme Liberata, where the king of Jerusalem gathers his officers after a crushing defeat to gauge varying reactions to the menaces of Goffredo's besieging army. ${ }^{58}$

In Tasso's version, the murmur of the people is interrupted by an advocate of war, Argante, who counts on the military virtues of the men in Jerusalem. ${ }^{59}$ Argante is opposed by Orcano, who argues that Jerusalem should surrender. Orcano points toward the menacing war machinery and the former victories of the besieger. Besides, he fears there will be a serious shortage of food in Jerusalem and doubts whether the Egyptian allies will actually arrive in time (X, 39-47). Orcano's statements provoke the intervention of a third man, Solimano, who silences everybody: if anyone even dares to speak of concluding a peace treaty, he, Solimano, will kill him personally $(\mathrm{X}, 51)$. This discussion in the Gerusalemme lent itself well to be transposed into the Anversa Conquistata (IV, 1-187), where

\footnotetext{
${ }^{58}$ The scene was modeled on the discussion between Turnus and Drances in the eleventh book of the Aeneid and reappears without radical modifications in the Gerusalemme Conquistata (XI, 46-70).

59 "Ma con la faccia baldanzosa e lieta / sorgendo Argante il mormorare accheta" (GL, X, 36, 7-8).
} 
the "feroce Argante" who "ripone / ne la spada sua legge e sua ragione,"60 is replaced by a young and equally ferocious Maurizio:

Stava fra due contrari il volgo in forse in due parti diviso, ${ }^{61}$ all'hor che in mezo sorse Mauritio, un giovine feroce, che ponea ne la spada ogni salute, vedendo il popol tutto aver conversi gli occhi in lui solo, e starsi intento, e cheto, parla con alta, et orgogliosa voce in cotal guisa a l'adunata stuolo.

(Anversa Conquistata IV, 23-30) ${ }^{62}$

Maurizio, whose arguments in favour of the battle are partially taken from the historical account of Cesare Campana (Assedio, 31-35), equally recommends the use of their weapons and assumes a furious attitude, which recalls especially the Argante of the Gerusalemme Conquistata. ${ }^{63}$ Like Argante, Maurizio receives a response in favour of peace. The role of Tasso's Orcano is here played by the old and wise Carlo, one of the most reputable men in the city. ${ }^{64}$ Carlo argues that the war has cost enough victims. As Orcano, he underscores that the people

${ }^{60} G L$, III, 59, 7-8.

${ }^{61}$ This definition also recalls the dissension in Troy about the fatal decision whether to destroy the wooden horse or to bring it inside the city: "Scinditur incertum studia in contraria volgus" (Aen. II, 39).

${ }^{62}$ Cf. "Ma con la faccia baldanziosa e lieta / sorgendo Argante il mormorare accheta" (GL X, $36,7-8)$

63 "Così parlò costui pien di dispetto, / scorto da l'alterezza, e dal furore, / qual furioso, e forsenato Aiace" ( $A C$, IV, 70-2); cf. "Cosí disse con occhi orror spiranti, / qual uom che parli di non dubbia cosa” (GCXI, 56, 1-2).

64 "Di sapere il buon Carlo colmo il seno, / novo Nestor fra i suoi, un de' più ricchi, / e de' più riveriti entro le mura, / ne le consulte riputato molto, / contra Mauritio così à dir s'accinse" ( $A C$, IV, 73-7); cf. "Poi sorse in autorevole sembiante / Orcano, uom d'alta nobiltà famosa, / e già ne l'arme d'alcun pregio inante" (GL X, 39, 3-5). 
are trapped in the city, where there is a serious shortage of food. ${ }^{65}$ Finally, Carlo advises what Orcano did not dare to propose: ${ }^{66}$

dunque havendo fortuna sì nimica, né potendo schifar quel, che ' 1 Ciel vuole, accordianci co'l Prence, ò pur co'l fato [...]

(Anversa Conquistata IV, 89-91)

Unlike the discussion in the Gerusalemme, in Antwerp there is no figure like Solimano to cut short the discussion by excluding the option of a peace treaty. Instead, the speech of the peaceful Carlo is amplified with flattering arguments in favour of Farnese. Besides comparing him to Hercules, Carlo reminds his fellow citizens of Alessandro's origins: since his own grandfather emperor Charles V was born in the Netherlands and his mother Margherita had reigned the provinces in "aurea pace," Carlo asserts that Alessandro could thus be considered one of them, a Fleming. ${ }^{67}$

Old Carlo's name suggests the connection with Charles V and emphasises the identification between Farnese and the inhabitants of the Low Countries. Maurizio, in contrast, seems to refer to Maurits of Nassau, the principal opponent to the Spanish crown in the Netherlands after the assassination of his father William of Orange in 1584. By adapting an existing epic theme to the specific historical context of the Dutch Revolt and by bringing on the scene two invented, though credible, characters with carefully chosen names, Sanvitale effectively

\footnotetext{
65 "E noi da la Steccata chiusi siamo, / tanto, che mal si può d'Anversa uscire, / onde già manca ad infiniti il cibo" ( $A C \mathrm{IV}, 86-8)$; cf. "Noi (se lece a me dir quell ch'io ne sento) / siamo in forte città di sito e d'arte, / ma di machine grande e violento / apparato si fa da l'altra parte. / Quel che sarà, non so; spero e pavento / i giudizi incertissimi di Marte, / e temo che s'a noi più fia ristretto / l'assedio, al fin di cibo avrem difetto" (GL X, 42).

${ }^{66}$ Cf. "Così diceva, e s'avolgea costui / con giro di parole obliquo e incerto, / ch'a chieder pace, a farsi uom ligio altrui / già non ardia di consigliarlo aperto" (GL X, 48, 1-4).

67 "Ma che dirò de la sua genitrice / sotto pur questo cielo in questo suolo, / nata fra noi del gran Carlo nostro, / che nacque in Gante, del famoso Alcide / via più famoso in trapassar la meta / d'Abila, e Calpe, a lui termine angusto? / Noi potiam dire, ch'Alessandro sia, / com'è, di sangue, d'animo fiammingo; / s'habbiam per arra, che di Margherita / Austriaca sia nato, la qual tenne / noi lungamente in aurea, e dolce pace" ( $A C \mathrm{IV}, 170-80$ ).
} 
represents the surrender of the city. Indeed, Carlo's arguments are convincing enough to result in a negotiation with the Catholic camp.

Some days later twenty-four city ambassadors make their way to Farnese in Beveren, where the eloquent Marnix asks "humil perdono" for the errors of his community. They will now believe in Alessandro, "Principe Roman di regio sangue," as a bearer of the golden age ${ }^{68}$ and are convinced that Alessandro is able to pardon those who show humility and kneel in front of him. ${ }^{69}$ He explains that their rebellion against the king originates from an innate desire for liberty, a feature that since Tacitus had been ascribed to the inhabitants of the Low Countries. ${ }^{70}$ Therefore it should be considered an error and not a sin. "La clemenza negli occhi," Farnese accepts Marnix's excuses and the peace is celebrated in a long fifth canto, entirely devoted to the solemn entry of Farnese into the city of Antwerp.

These examples show how the discussion of the Gerusalemme Liberata has been adapted in order to culminate in a reconciliation. The author thus found a solution for representing the peaceful triumph of a general, whose aim was neither the total destruction of the enemy, nor the re-conquest of a sacred city, but the reconversion of a wandering community. ${ }^{71}$ Obviously, a similar solution

68 "Che per Te spera di veder la prisca, / e desiata età del secol d'oro" (AC IV, 211-2).

69 "Te legare altrui può con l'humiltate, / che proprio è tuo di perdonare a quelli, / che s'inchinano a Te" (AC IV 215-7). And at the end of his speech: "E come vinta a Te s'arrende, e chiede / humil perdono, e da Te solo aspetta / quelle condition', che da i Romani / duci benigni haver soleano i vinti, / anzi ancore più pie, quanto più pio, / et humano Tu sei di Giulio, e Druso, / e di Marcello, e del felice Augusto, / sotto cui vidde il Mondo un'aurea etate" (AC IV, 242-9).

${ }^{70}$ Y. Rodriguez-Perez, The Dutch Revolt through Spanish eyes. Self and Other in Historical and Literary texts of Golden Age Spain (1548-1673) (Berlin, Peter Lang, 2008), pp. 28-31.

${ }^{71}$ Another example of a peaceful epic solution can be found in the narration of the siege of La Rochelle (1627-1628) by Francesco Bracciolini, see Giachino, "Dalla storia al mito.” The printer of the Roccella Espugnata (Rome, Mascardi, 1630) mentions in the preface to the first fifteen cantos how the narration was going to end in the five remaining chapters, which were never published. The poem would probably have had a similar ending as the Anversa Conquistata: "lo Spirito Santo spira i Roccellesi a rendersi. Si raduna il Consiglio, e il Governatore parla, e mostra che la città non si può più mantenere, onde il Senato elegge sei Ambasciatori, che vanno al Re, e gli domandano perdono, promettendogli, e giurandogli fedeltà. Il Re glielo concede [...] Gli ambasciatori si partono contenti, \& il Re fa apprestare il cibo per ristorare i Roccellesi, e promette il giorno seguente di far l'entrata nella Città. [...] Il Re con incredibil pompa, e magnificenza se n'entra nella città, e gli escono incontro cinquanta Senatori, che gettandoglisi ai piedi gli domandano piangendo perdono, e pietà. Il Re scordandosi d'ogni lor mancamento 
was useful, above all, to the framing of Alessandro Farnese as a pious peacemaker, a Holy Shepherd, whose clemency allowed the heretics to return to their Catholic origins.

\section{The pious hero}

Thus the major goal of the Anversa is not so much the dramatic narration of a highly symbolic siege in itself, rather the celebration of its hero Alessandro Farnese. The importance of the encomiastic purpose becomes clear, not only from the choice of subject and the insertion of praise for Farnese, as expressed by the Antwerpians, but also through the narrator's use of topoi belonging to the epic tradition. The incipit of the Anversa Liberata manifests the poet's skill in creating meaning through the alignment of his poem with the tradition.

L'armi del Ciel ministre e 'l pio guerriero

Ch'Anversa all'Eresia ritolse io canto [...]

(Anversa Liberata I, 1-2)

Just like Aeneas and Goffredo before him, Farnese is a pious hero. Although the epithet "pious" was one of the most frequent characterizations of post-Tassian heroes, ${ }^{72}$ it is associated with the Anverse in a particular attribute of the hero's ethos, that is, his mercifulness. According to the Vocabolario degli accademici della Crusca of 1612 "pio" not only meant religious or devout, but also merciful and compassionate ("misericordioso, pietoso"). While Goffredo is exemplarily merciful towards his own soldiers, still, he has to conquer the besieged city with a cruel battle and in the Gerusalemme Liberata arrives at the holy sepulchre wrapped in his "sanguinoso manto" (XX, 144, 5). The authors of the Anverse could avoid ending their poems with controversial images of a bloody captain, and insist instead on the interpretation of "pious" as forgiving.

The aforementioned prayer in favour of the people of Antwerp, by which Farnese demands that his sword will not have to bring the whole city of Antwerp

gli appella due, e tre volte amici, e giunge al tempio, dove ringrazia Dio del trionfo; si parte, e se ne torna al suo alloggiamento."

${ }^{72}$ As Antonio Belloni concluded, amongst the principal characters of seventeenth-century epic poetry, there is always that of the "duce supremo, sempre pio, come Goffredo, e prediletto del Signore," Gli epigoni della Gerusalemme Liberata (473). 
to death (III, 17, 1-3), reveals that he aspires to be neither a terrifying Achilles nor a bloody Goffredo, but a merciful leader, capable of unifying the divided Christian community. The prayer is answered by his guardian angel, who takes Farnese into heaven and promises him eternal glory as a reward for his past and future deeds (III, 13-25). Farnese's virtual ascension appears in many terms as a calque of Goffredo's dream in canto XX of the Gerusalemme Conquistata, from which the Anversa Liberata borrows, amongst other elements, the encomiastic framework and the apocalyptical description of Heaven's inhabitants. ${ }^{73}$ Alessandro's humble reply to the angel points once again to the image of a pious hero:

- Dunque - risponde - a tant'onore s'adduce

vil fango, anima vil, d'uom peccatore?

Ed io che son? Che fei? Celeste è dono

quel ch'io fo, quel ch'io penso e quel ch'io sono.

Null'ho di mio, se non le colpe: e queste

pregate voi che 'l mio Signor mi tolga,

sì che nel petto misero non reste

macchia onde 'l guardo schivo indi rivolga

(Anversa Liberata III, 26, 5-27, 4)

Farnese not only ascribes all his merits to God (as Goffredo did in the Gerusalemme Liberata), but also asks to be purged from his sins. ${ }^{74}$ After this declaration, the guardian angel shows him the inhabitants of Heaven. While promising him eternal celestial glory if he continues the fight for God (XIV, 7-8), the angel

\footnotetext{
${ }^{73}$ For a close examination of Goffredo's dream see Gigante, "Il sogno." This recourse to the Gerusalemme Conquistata instead of the more popular Liberata characterizes the author's postTassianism and highlights the underestimated fortune of the Gerusalemme Conquistata and its aptness to figure in Counter-Reformatory contexts. The Gerusalemme Conquistata offers a complementary intertextual level to the Dantesque dimension in Alessandro's dream discussed by Marco Arnaudo, and could nuance his insight that 'al terzo canto del testo si trova una visione paradisiaca che risente molto più della Commedia che della Liberata'; see Dante barocco. (96-97).

${ }^{74}$ Cf. "Turchi, Persi, Antiochia (illustre suono / e di nome magnifico e di cose) / opre nostre non già, ma del Ciel dono / furo" (GL I, 26). In the Gerusalemme it was Rinaldo rather than to Goffredo to be purged, in order to be reintegrated in the army and conquer Jerusalem (XVIII, 7-9).
} 
indicates the latest defenders of the Catholic faith. A similar vision of the tempio di Dio had already given rise to an encomiastic triumph of fame in Gerusalemme Conquistata XX. Yet, while Tasso's dream contains a long catalogue of spiritual and earthly leaders, a "vero e proprio museo della virtù guerriera," ${ }^{\prime 5}$ the short list of exemplary heroes in the Anversa Liberata is limited to past members of the Farnese family. Significantly, the first man to be introduced to Alessandro in the Anversa Liberata is his ancestor Pope Paul III: remembered in the poem for his exemplary role as a punisher of vices and a holy shepherd, ${ }^{76}$ he had also created the duchy of Parma and Piacenza for the Farnese family. The celestial representation of Paul III in a poem celebrating a Farnese is significant, for it reinforces the divine motivation and legitimation of the earthly power and successes of the Farnese family. The encomiastic topos of the prophetic revelation of the hereafter thus places the heroic deeds of the Farnese in a dynastic line, which is tacitly projected into the future, to the dedicatee of the Anversa Liberata Odoardo Farnese. ${ }^{77}$

Farnese's sacred piety is further underscored by other adaptations of common places of the epic tradition. As we mentioned above, his helpers are his mother Margherita of Austria, his guardian angel and the Virgin Mary herself. The chain of assistance can be reconstructed as Alessandro - Margherita - Holy Virgin — God and the Holy Son and back again: a quite exaggerated vertical representation of the controversial celestial hierarchy. ${ }^{78}$ Contrary to other heroic poems, which typically combined "arme e amori," divine love and maternal affection are the only apparitions of love in the Anversa Liberata. Moreover, divine love is represented as the driving force behind both the heroic piety of Farnese and the inspiration of the poet: following Tasso, the classical invocation to the Muse at the

\footnotetext{
${ }^{75}$ Residori, L'idea (154).

76 "chiamò con dolci modi e gravi / allo smarrito ovil l'agnelle perse" (AL III, 32). The author further refers to the excommunication of Henry VIII $(A L$ III, 31) and the unification of the "menti averse" of Europe's leaders accomplished by Paul III ( $A L$ III, 32), reminding the reader of his key role in the end of the Italian War of 1536-1538. Another merit of Paul III is the convocation of the Council of Trent.

${ }^{77}$ Since the manuscript contains neither date nor author and the internal references are scarce, it is not clear whether the name of Odoardo in the dedication (" $\mathrm{Tu}$, del sol de gli eroi celeste prole, / serenissimo onor d'ogni suo raggio, / prendi, Odoardo, il suo bel carro, e vole / tra' segni de' suo' fatti il tuo viaggio" ( $A L \mathrm{I}, 4,1-4)$ refers to Alessandro's son (cardinal, 1573-1626) or to his grandson (duke of Parma and Piacenza, 1612-1646).

${ }^{78}$ On this theme in Tasso, see Casella, "La Gerusalemme contro-riformata" (118-119).
} 
beginning of the poem is substituted by an appeal to the "sacra fiamma d'amore,"79 while it is the same godly "fiamma d'amore" that inspires Alessandro's confession of humbleness in front of his guardian angel (III, 26). Moreover, in line with his aversion for civilian blood, Farnese never reveals his fighting skills in the Anversa Liberata. His role is limited to good military leadership, under the eloquent motto: "eroe non prende/ solamente dal brando i pregi suoi" (I, 5). ${ }^{80}$ It was perhaps this set of 'piteous', Counter-Reformatory qualities that the author of the Anversa Liberata wanted to ascribe to Alessandro and his helpers, which conditioned the choice of representing only the siege of Antwerp. After all, the author could also have chosen the fierce siege of Maastricht (1579) as his subject, where the same hero had been responsible for thousands of civilian victims and heavy plundering of the city. ${ }^{81}$ The representation of Farnese as an extremely devout hero is the main concern in the whole third canto of the Anversa Liberata, which is permeated by a rigorous Catholic tone. ${ }^{82}$ After his vision, Farnese attends a Catholic Mass in the already reconverted neighbourhoods of Antwerp. The description of this service is particularly detailed, but the largest part of the canto is dedicated to the evocation of the space. The author situates the Mass in a magnificently decorated church, emphasizing the material manifestations of splendour. A central position is assumed by a series of tapestries, which gives rise to an elaborate ecphrasis of scenes from the Old Testament. While the description of the tapestry representing the Temple of Salomon figures as a mise en abyme of the Counter Reformation aiming to re-appropriate the institution of the Church (III, 67-70), two other tapestries represent more direct allegories of Farnese's role: the first concerns the passage of the Red Sea (III, 55-9), the second the making of the Tabernacle and the bronze serpent (III, 60-6). Their primary function is to introduce a second level in the narration, in which a parallel image of the hero is created. As designated leader of the elected people, Moses functions as a biblical prefiguration of Alessandro. The

\footnotetext{
${ }^{79}$ Cf. GL, I, 2, where Tasso replaced the classical Muse of the Helicon with a celestial one.

${ }^{80}$ This stress on other virtues rather than on warfare skills could support the identification of the dedicatee with Alessandro's son, who had become cardinal in 1591.

${ }^{81}$ For the difficulties Tasso had envisaged by making his principal hero a leader of the massacre in Jerusalem, see Murrin, History (204-210). In the Gerusalemme Conquistata, the motive of the cruel siege lost strength through the displacement of the final battle to Ascalon; see Gigante, Vincer pariemi (102-3).

${ }^{82}$ This aspect has been studied in detail in Grootveld, "Arazzi ad Anversa."
} 
tapestry of the Red Sea may recall that both Alessandro and Moses defeated their enemy by controlling the water and this, more importantly, through providential assistance. The parallel is more evident in the second tapestry, which represents the bronze snake. God punished the rebellion of the disgruntled Hebrews by sending them snakes and ordered Moses to produce a snake of bronze to resolve their suffering:

Scorgi che dotta man di bronzo forte

Dell'angue micidial forma il sembiante,

sì ch'un girar di ciglio e l'empia morte scaccia e l'error del popolo incostante.

Potea celeste man cangiar la sorte, torre o 'l veleno o 'l serpe in un istante: ma svela in guisa tal la data legge, onde vieta i sembianti ei che gli elegge. (Anversa Liberata III, 66)

Together with some deleted stanzas on the episode of the golden calf, ${ }^{83}$ this octave refers to Moses' intermediate position between God and the people: his role is to correct the "inconstant people" on behalf of God by imposing them the "given laws" and by punishing them for idolatry and rebellion. The contemporarily represented fabrication of the Tabernacle ratified the subsequent renewed pact with God. This symbolization of divine punishment and subsequent redemption, after an episode of religious errancy and rebellion, could again be seen as a parallel with the Calvinists of Antwerp. Complementary to this image, the hero emerges as a carrier of salvation, since his task is to bring the wandering community back to the right path. The ecphrasis of the Anversa Liberata contributes in this way to the representation of Farnese's mission as a moral and religious question.

This is, in part, different for the Anversa Conquistata. The apologetic scene discussed in the previous paragraph rather focuses on the civil disobedience of the people of Antwerp, for which Farnese's role assumes a more political dimension in comparison with the Anversa Liberata. It is therefore not surprising that the dynastic line exalting Alessandro and his descendants is connected to his grandfather Charles V, instead of his paternal ancestor Paul III. The emperor appears, not only in the praise of his Flemish namesake Carlo and in Alessandro's dream, at the

${ }^{83}$ Cf. pp. $186-7$ of the cited edition. 
beginning of the first book, but also in the final scenes of the Anversa Conquistata. In the fifth and last canto the ambassadors of Antwerp offer Farnese a tapestry as a homage for the peaceful capitulation of Antwerp. This gift-giving takes place immediately after the chant of a bard, who melodiously enumerates various campaigns of Charles V, from the battle of Mohàcs (1526), to the siege of Saint-Dizier (1544). After Charles, it is Alessandro's turn to stand in the spotlight. The tapestry he receives represents the battle of Lepanto. After having recognized his uncle Don Juan and other participants in the battle, Farnese recognizes himself while fighting the Ottomans. ${ }^{84}$ By subsequently making use of two similar retrospective and encomiastic techniques (first the chant of Charles and then the ecphrasis of his grandson at the battle of Lepanto), ${ }^{85}$ the poet underlines the continuity between Farnese and Habsburg's imperialism. At the same time the tapestry links the Anversa Conquistata to the literary tradition in which it finds its origins, by triggering a connection with the battle of Actium, which had taken place not far from there in 31 B.C. At Actium, Octavian triumphed over Mark Antony and Cleopatra's combined forces, during what would become one of the most typical 'imperial' victories in European literature, as it marked the beginning of the Augustan Age. ${ }^{86}$

The memory of Farnese's precedents in epic and history gave the hero a mythical aspect, which perfectly responded to the historical role that his celebrator attributed to him. This image is coherently carried over in the rest of the Anversa Conquistata, where Farnese is constantly compared to Roman rulers. His pompous triumphal entry in Antwerp in the fifth and last canto is described as a solemn imperial event, "de gli antichi in guisa" (p. 80). In this way, the triumph obtained by Alessandro Farnese after the siege of Antwerp can for both poems rightly be defined as a Roman victory. While the Anversa Liberata gives a religious interpretation to Alessandro's pietà, by associating him with the typical values of the Catholic Church and to a biblical precedent, in the Anversa Conquistata his celebration rather pivots on the imperial aspects of his personality. In both poems

\footnotetext{
${ }^{84}$ This happened similarly to Aeneas while contemplating the frescoed battle of Troy in the temple of Iuno near Carthage (Aen I, 488-9).

${ }^{85}$ Bruscagli, "L'ecfrasi dinastica” (269-292).

${ }^{86}$ Quint, Epic (21-49). As such, it is remembered by Sanvitale: "Sorser già di Corinto, emule al Cielo. / Quinci l'Epiro, e 'l Cefalenio lido, / Et quindi l'Attio, che à mirar d'Augusto / Hebbe, e d'Antonio la naval tenzone, / (Quasi luogo fatale à grandi imprese)," Anversa Conquistata V, 15-9.
} 
however, Alessandro assumes a particular predisposition to forgive his enemy for having renegaded the authority he aims to re-establish, whether that authority was represented by the Roman-Catholic Church or by the Habsburg supremacy.

\section{Conclusion}

The intertextual analysis of the Anversa Liberata and Anversa Conquistata has demonstrated how epic literary schemes, that were originally used for the narration of a crusade against Islamic infidels, could be adapted to the representation of a reconversion campaign of a Calvinist community in post-Tassian poems. Written some decades after the conquest of Antwerp in 1585, these poems cast a protagonist who acts as a true Catholic hero of his time. In their constructions of Alessandro Farnese's character, the authors draw particularly on the Virgilian idea of a pious hero, devout and merciful towards those who deserved forgiveness. In both poems, Farnese assumes a particular predisposition to forgive his enemies for their mistakes towards the Roman Catholic Church and Habsburg authority. His ethos makes it possible to fit the historical siege in a post-Tassian epic scheme, because he imitates Goffredo's merciful attitude towards the Christian rebels instead of his massive crush of the pagans. Farnese's 'crusade' consists of a reconquest and reconversion of Antwerp, a mission represented as a moral duty, for the hero has the task to bring the Low Countries onto the right path and to impede further dissemination of heresy. This task entails a shift of perspective vis a vis the most important literary models of the poems, Tasso's Gerusalemme Liberata and Conquistata. The enemies in the Anversa are heterodox but still Christians: they could be pardoned as a community, while this is barely the case for the Muslim enemy in Tasso's poems. The double status of the enemy as both besieged opponents and wandering Christians, led to a vital adaptational interplay of passages from the Gerusalemme. Firstly, both poems show allusions or similarities with Tasso's pagans like Argante or Ismeno, and also with Argillano's revolt in the eighth canto of the Gerusalemme. They thus seem to confirm the parallel between the rebelling soldiers of Goffredo and the rebelling Protestants of sixteenth-century Europe. Secondly, the historical end of the siege required the mise-en-scène of a surrender, instead of a violent capture of the city, for which the author of the Anversa Conquistata duplicated the council of the besieged citizens of his Tassian models (GL X, 34-56; GC XI, 46-70) and adapted it to the historical circumstances. This interplay between literary, historical and political elements 
in both poems shows the versatility of bellicose epic models: these models could be adapted to narrate a specific contemporary conflict and offer a framework for what we can call 'encomiastic poems of reconciliation'.

University of Leuven

\section{Works Cited}

\section{Primary sources}

Ariosto, Ludovico. Orlando Furioso e cinque canti. Ed. Remo Ceserani and Sergio Zatti, 2 vols. Turin: UTET, 2006 (1997).

Bracciolini, Francesco. La Roccella Espvgnata. Rome: Mascardi, 1630.

Campana, Cesare. Assedio e racquisto d'Anversa. Vicenza: Giorgio Greco, 1595. . Della Guerra di Fiandra. Vicenza: Giorgio Greco, 1602.

Caro, Annibale. L'Eneide di Virgilio, del commendatore Annibal Caro. Venice: Bernardo Giunti \& fratelli, 1581.

Chapelain, Jean. Lettre ov Discovrs de M. Chapelain [...] portant son opinion sur le Poëme d'Adonis du Cheualier Marino. In Giovan Battista Marino, L'Adone, Paris: Oliviero di Varano, 1623.

Maggi, Girolamo. Cinque primi canti della guerra di Fiandra. Venice: Al segno del Diamante, 1551.

Marino, Giovan Battista. Anversa Liberata, tre canti inediti. De’ Capelli di Sta Maria Maddalena, due odi inediti. Ed. Fernando Salsano. Bologna: Commissione per i testi di lingua, 1956.

Olivieri, Anton Francesco. La Alamanna. Venice: Vicenzo Valgrisi, 1567. . Carlo Quinto in Olma. Venice: Vicenzo Valgrisi, 1567.

Sanvitale, Fortuniano. Anversa Conquistata. Parma: Erasmo Viotti, 1609.

Tasso, Torquato. Gerusalemme liberata. Ed. Franco Tomasi. Milan: Biblioteca Universale Rizzoli, 2009.

. Gerusalemme Conquistata. Ed. Luigi Bonfigli. Bari: Laterza, 1934.

Ursus, Aurelius (Aurelio Orsi). De Bello Belgico. Perugia: Andrea Bresciano, 1586. Savorgnano, Giovanni, ed. Raccolta di diverse compositioni sopra le vittorie acquistate in Fiandra dal Serenissimo Alessandro Farnese Duca di Parma, et di Piacenza. Parma: Erasmo Viotti, 1586. 


\section{Secondary Sources}

Arbizzoni, Guido, ed. Dopo Tasso. Percorsi del poema eroico. Atti del convegno di studi, Urbino, 15 e 16 giugno 2004. Rome: Antenore, 2005.

Arnaudo, Marco. Dante barocco. Linfluenza della Divina commedia su letteratura e cultura del Seicento italiano. Ravenna: Longo Editore, 2013.

Belloni, Antonio. Gli epigoni della Gerusalemme Liberata Con un'appendice bibliografica. Padua: A. Draghi, 1893.

Blanco, Mercedes and Béhar, Roland, eds. Les Poètes de l'Empereur. La cour de Charles-Quint dans le renouveau littéraire du XVI siècle (1516-1556). E-Spania, June 2012: http://e-spania.revues.org/20968 (last accessed on 4th of December 2013).

Bolzoni, Lina. "An Epic Poem of Peace: The Paradox of the Representation of War in the Italian Chivalric Poetry of the Renaissance," in Marco Formisano and Hartmut Böhme, eds. War in Words, 19. Transformations of War from Antiquity to Clausewitz. Berlin and New York: De Gruyter, 2010. 271-290.

Bonardi, Pietro. Fortuniano Sanvitale "delli Conti di Sala." Letterato e pittore. Sala Baganza: Editoria Tipolitotecnica, 2003.

Bruscagli, Riccardo. "L'ecfrasi dinastica nel poema eroico del Rinascimento," in Ecfrasi. Modelli ed esempi fra medioevo e rinascimento. Eds. Gianni Venturi and Monica Farnetti. Rome: Bulzoni, 2004. 269-292.

Casella, Paola. "La Gerusalemme contro-riformata del Tasso: raffronti e linee di forza," Lezioni bellinzonesi 4 (2011). 106-136.

Cerbo, Anna, "Camôes e Tasso: l'Oriente nel poema eroico," Between, I.2 (2011), http://www.Between-journal.it/

Darby, Graham. The Origins and Development of the Dutch Revolt. London and New York: Routledge, 2001.

De Groof, Bart. "Alexander Farnese and the origins of modern Belgium." In Bulletin de l'institut historique Belge. La dimensione europea dei Farnese. Rome, 1993.

De Keyser, Joey. Vreemde Ogen. Een kijk op de Zuidelijke Nederlanden 1400-1600. Antwerp: Meulenhoff-Manteau, 2010.

Denarosi, Lucia. L'accademia degli Innominati di Parma: teorie letterarie e progetti di scrittura (1574-1608). Florence: Società Editrice Fiorentina, 2003.

Foltran, Daniela. Per un ciclo tassiano. Imitazione, invenzione e "correzione" in quattro proposte epiche fra Cinque e Seicento. Alessandria: Edizioni dell'Orso, 2005. 
Giachino, Luisella. "Dalla storia al mito. La Roccella Espugnata di F. Bracciolini." Studi secenteschi, 44 (2003): 168-194.

Gibellini, Cecilia. L'immagine di Lepanto. Venice: Marsilio Editore, 2008.

Gigante, Claudio. "Il sogno di Goffredo," Studi tassiani XLIII (1995): 7-30. . Vincer pariemi piu se stessa antica: La Gerusalemme conquistata nel mondo poetico di Torquato Tasso. Naples: Bibliopolis, 1996.

Girardi, Mariateresa. Tasso e la nuova "Gerusalemme." Studio sulla "Conquistata" e sul "Giudicio." Naples: Edizioni Scientifiche Italiane, 2002.

Grootveld, Emma. "Arazzi ad Anversa. Ecfrasi dopo Tasso," in Civiltà italiana, Nuova serie VII, L'Italia e le arti. Atti del XX Convegno dell'Associazione Internazionale dei Professori di Italiano, Salisburgo, 5 - 8 settembre 2012 (Forthcoming)

Hester, Nathalie. "Failed New World Epics in Baroque Italy." In Anthony J. Cascardi and Leah Middlebrook, eds. Poiesis and Modernity in the Old and New Worlds. Nashville: Vanderbilt University Press, 2012. 201-223.

Lombaerde, Piet. "Antwerp in its golden age" in Patrick O'Brien, ed. Urban Achievement in Early Modern Europe: Golden Ages in Antwerp, Amsterdam and London. Cambridge: Cambridge UP, 2001. 99-107.

Mammana, Simona. Lèpanto: rime per la vittoria sul turco. Regesto (1571-1573) e studio critico. Rome: Bulzoni, 2007.

Marnef, Guido. "Burgemeester in moeilijke tijden: Marnix en het beleg van Antwerpen." In Henk Duits and Ton Van Strien, eds. Een intellectuele activist. Studies over het leven en werk van Philips van Marnix van Sint-Aldegonde. Hilversum: Uitgeverij Verloren, 2001.

Moretti, Silvia. "La trattatistica italiana e la guerra: il conflitto tra la Spagna e le Fiandre" Annali dell'Istituto storico italo-germanico in Trento, 20 (1994): 129-164.

Murrin, Michael. History and Warfare in Renaissance Epic. Chicago and London: U of Chicago P, 1994.

Nori, Gabriella. "Una biografia parallela di Alessandro Farnese: Pomponio Torelli e Cesare Campana” Aurea Parma, March-June (1978): 33-41.

Parker, Geoffrey. The Dutch Revolt. London: Cornell UP, 1977.

Pedullà, Anna Maria, Il romanzo barocco ed altri scritti. Naples: Liguori, 2001.

Residori, Matteo. L'idea del poema. Studio sulla "Gerusalemme Conquistata" di Torquato Tasso. Pisa: Scuola Normale Superiore, 2004. 
Rodriguez Pérez, Yolanda. The Dutch Revolt through Spanish Eyes. Self and Other in Historical and Literary Texts of Golden Age Spain (1548-1673). Berlin: Peter Lang, 2008.

Russell, Jeffrey B. Dissent and Reform in the Early Middle Ages. Berkeley: U of California Press, 1965.

Russo, Emilio. Autografi dei letterati italiani. I. Il Cinquecento. Rome: Salerno Editrice, 2009.

Quint, David. Epic and Empire. Politics and Generic Form from Virgil to Milton. Princeton: Princeton UP, 1993.

Sabbadini, Roberto. "L'uso della memoria. I Farnese e le immagini di Alessandro, duca e capitano." In Marcello Fantoni, ed. Il Perfetto Capitano: immagini e realtà, secoli XV-XVII. Atti dei seminari di studi Georgetown University a Villa "Le Balze." Istituto di studi Rinascimentali di Ferrara, 1995-1997. Rome: Bulzoni, 2001: 160-179.

Saccenti, Mario. Libri e maschere del Seicento italiano. Florence: Le Monnier, 1972.

Salsano, Fernando. "Fortuniano Sanvitale" Studi Secenteschi 5 (1964): 69-92.

Scavizzi, Giuseppe. "Gerusalemme Liberata e Controriforma" Quaderni d'Italianistica IX, 2 (1988): 199-227.

Soen, Violet. "Reconquista and reconciliation in the Dutch Revolt: The Campaign of Governor-General Alexander Farnese (1578-1592)" Journal of Early Modern History 16 (2012): 1-22.

Turchi, Marcello. "Riflessi letterari in Italia della battaglia di Lepanto" Nuovi quaderni del Meridione, IX, 36 (1971): 390-392.

Van der Essen, Leon. Alexandre Farnèse, Gouverneur-Général des Pays-Bas (15451592), 5 vols. Brussels: Librairie nationale d'art et d'histoire, 1933-1935. . "Alexandre Farnèse, Homme d'état chrétien." In Miscellanea Vermeersch. Rome: Pontificia Università Gregoriana, 1935.

Volpicella, Filippo. "Di un poema e due odi sacre inedite del Cav. Giambattista Marini' Annali Civili del Regno delle Due Sicilie 6 (1834-3). 55-60.

Zatti, Sergio. The Quest for Epic. From Ariosto to Tasso. Toronto: U of Toronto Press, 2006. . La rappresentazione dell'altro nei testi del Rinascimento. Ed. Lucca: Maria Pacini Fazzi editore, 1998. 
